PRZEGLĄD NAUK HISTORYCZNYCH 2020, R. XIX, NR 1

http://dx.doi.org/10.18778/1644-857X.19.01.11

\title{
„Bayreuthiana" jako źródło do badań nad historia drugiej wojny światowej w świetle sprawozdania urzędnika niemieckiego o getcie lódzkim jako case study
}

Streszczenie. Prezentowany artykuł opisuje zasoby materialne, źródłowe pod nazwa Ost-Dokumentation (Dokumentacja Wschodnia). W świetle zdeponowanych w tym zespole relacji autor przedstawia warunki życia ludności żydowskiej $\mathrm{w}$ getcie łódzkim podczas drugiej wojny światowej w świetle zachowanego sprawozdania jednego $z$ niemieckich urzędników. Relacja ta została spisana po zakończeniu wojny i umieszczona w zespole archiwalnym przechowywanym w niemieckim mieście Bayreuth. Od nazwy tego miasta autor wprowadził określenie „Bayreuthiana" dla zespołów archiwalnych znajdujacych się w tamtejszym Bundesarchiv - Archiwum Federalnym w Bayreuth, w Bawarii, w Republice Federalnej Niemiec. „Bayreuthiana” to pojęcie niefunkcjonujace wcześniej w historiografii polskiej i niemieckiej. Zespoły archiwalne tam zdeponowane stanowią bogate źródło informacji o historii społecznej, stosunkach międzyludzkich, relacjach polsko-niemieckich w okresie międzywojennym, także w czasie drugiej wojny światowej i po 1945 r. Niewątpliwie „Bayreuthiana” w formie relacji pisemnych osób maja charakter bardzo subiektywny. Sa jednak pewnym, specyficznym źródłem informacji. Jedna $z$ takich relacji, sprawozdań liczy trzy strony i dotyczy getta łódzkiego. Autorem jest Friedrich Prager, który był urzędnikiem wyższego szczebla podczas wojny. Po wojnie osiadł w Garmisch-Partenkirchen i w 1955 r. sporzadził swoją relację. W relacji przedstawia getto łódzkie, warunki w nim panujące, życie codzienne, zachowania ludności żydowskiej. Próbuje przedstawić warunki życia Żydów w getcie jako w miarę normalne, pokazując funkcjonowanie różnych instytucji, takich jak sklepy, apteki, szpitale.

Słowa kluczowe: druga wojna światowa, polityka ludobójstwa Trzeciej Rzeszy, ludność żydowska, getto łódzkie, życie codzienne w getcie, źródła archiwalne.

\footnotetext{
*E-mail: w.stankowski@instytutpileckiego.pl
} 
B ayreuthiana" jest to nowe pojeccie wprowadzone przez autora na potrzebę artykułu. Próba wprowadzenia tego pojęcia do historiografii ma służyć zwróceniu uwagi na zespoły archiwalne, które znajduja się w Bundesarchiv - Archiwum Federalnym w mieście Bayreuth, w Bawarii, w Republice Federalnej Niemiec (dalej: RFN). Zespoły archiwalne w Bayreuth to przede wszystkim relacje osób, Niemców, także i inne materiały archiwalne, które odnoszą się do czasów drugiej wojny światowej, a przede wszystkim do okresu powojennego. Relacje osób są niewątpliwie zapisem bardzo subiektywnym, wymagajacym od badacza krytyki źródłowej. Wnosza jednak istotne informacje do zrozumienia stosunków międzyludzkich pomiędzy Polakami, Żydami, Niemcami, osobami pochodzacymi z ZSRR.

Przyjęte określenie „Bayreuthiana” wywodzi się od miasta Bayreuth, które po zjednoczeniu Niemiec w 1990 r. stało się siedziba - filią Archiwum Federalnego (Bundesarchiv). Zbiory, które trafiły do Bayreuth, znajdowały się wcześniej w Koblencji w kraju związkowym Północna Nadrenia-Westfalia. Archiwum Federalne w Koblencji było centralnym archiwum federalnym (Hauptdienststelle Koblenz) w Republice Federalnej Niemiec. Usytuowanie centralnego archiwum federalnego właśnie w Koblencji wynikało z bliskiego położenia stolicy RFN w Bonn. W archiwum tym były deponowane również akta wytwarzane przez Urząd Federalny. Po zjednoczeniu Niemiec 3 października 1990 r. nastąpiły zmiany w strukturze archiwum niemieckiego. Została zreorganizowana struktura archiwów niemieckich, która swoim zasięgiem objęła zarówno część zachodnią Niemiec, jak i wschodnia, czyli obszary dawnej Niemieckiej Republiki Demokratycznej (dalej: NRD).

$\mathrm{Z}$ początkiem lat dziewięćdziesiątych XX w. nastąpiło przenoszenie akt do nowych miejsc-archiwum, nie tylko na teren dawnej NRD, lecz także do nowo powstałych placówek. Od podstaw utworzone archiwum powstało właśnie w Bayreuth w latach 1995-1999, a na jego siedzibę wyremontowano dawny szpital miejski ${ }^{1}$. Ogólne koszty adaptacji i przystosowania budynku do celów archiwalnych wyniosły wówczas 30 milionów marek niemieckich.

W Archiwum Federalnym w Bayreuth zostały zdeponowane trzy rodzaje zbiorów archiwalnych. Jeden $z$ nich to zasoby, które określane sa jako akta kompensacyjne (Lastenausgleichsarchiv).

${ }^{1}$ Lastenausgleichsarchiv Bayreuth. Baudokumentation, Staatliches Hochbauamt Bayreuth, Bayreuth [b.d.]. 
Są to różnorodne materiały, które posiadali czy też zbierali Niem$\mathrm{cy}^{2} \mathrm{w}$ celu udokumentowania i uzyskania odszkodowania od rza$\mathrm{du}$ niemieckiego za utracony majątek w Europie Wschodniej. W zespole tym znajduja się takie artefakty, dokumenty, jak wyciagi $z$ ksiag wieczystych, książeczki oszczędnościowe, plany domu bądź gospodarstwa, zdjęcia itp. materiały. $\mathrm{Na}$ ich podstawie wypłacano po wojnie Niemcom odszkodowania. Do tego zbioru archiwalnego nawiazuje sama nazwa archiwum jako Lastenausgleichsarchiv Bayreuth.

Kolejny zbiór archiwalny obejmuje relacje Niemców zamieszkujacych tereny Europy Środkowo-Wschodniej, takie państwa, jak Polska, Czechosłowacja, Węgry, Rumunia, Jugosławia, Związek Sowiecki. Archiwalia te sa opatrzone określeniem Ost-Dokumentation, czyli Dokumentacja Wschodnia.

Trzeci rodzaj materiałów archiwalnych to akta poszukiwań osób zaginionych w wyniku działań wojennych podczas drugiej wojny światowej. Sa to akta w formie rejestru Niemców, którzy zamieszkiwali tereny obecnej Europy Środkowo-Wschodniej i Południowej. Zespół ten nazywa się Heimatortskartei. Zawiera informacje o nazwiskach Niemców zamieszkałych w danej wsi, gminie, danym powiecie. Rejestry te były uzupełniane o wiadomości o losach osoby zaginionej, deportowanej od tych, którzy przeżyli wojnę. Zespół ten liczy 20 milionów kart osobowych.

Szczególnie interesujacy do badań historycznych, socjologicznych, interdyscyplinarnych jest zbiór archiwalny Ost-Dokumentation, czyli Dokumentacja Wschodnia, funkcjonujący pod pojęciem Ost-Dok. Po drugiej wojnie światowej RFN rozpoczęła zbieranie i gromadzenie informacji o powojennych losach swoich rodaków w Europie Środkowo-Wschodniej. Informacje te pochodziły z relacji pisemnych. Za pośrednictwem prasy i innych mediów zaapelowano do Niemców o spisywanie swoich przeżyć. Relacje te były skrupulatnie gromadzone i archiwizowane. W celu usystematyzowania potencjalnych informacji od sprawozdawcy zostały przygotowane konkretne formularze $z$ pytaniami (Fragebogenberichte). Ich celem było sporządzenie obrazu losów Niemców w poszczegól-

${ }^{2}$ Chodzi tu o tych Niemców, którzy po drugiej wojnie światowej określali sami siebie jako wypędzeni (Vertriebene). Określenie to, mające pokazać cierpienia Niemców oraz sposób ich potraktowania przez państwa zwycięskie po drugiej wojnie światowej (utrata domostwa, wszelkiego stanu posiadania) zostało włączone w oficjalny obieg i stało się w RFN pojęciem ogólnie obowiązującym. 
nych gminach, powiatach, miastach od momentu bezpośrednich walk do ich opuszczenia na przełomie 1944 i 1945 r., czyli pod koniec wojny. Zapytania dotyczyły przeprowadzenia ewakuacji, drogi ucieczki, walk o gminę, powiat, miasto, tworzenia sowieckiej i polskiej administracji, losów danej osoby, jej rodziny w pierwszych dniach nowej administracji. Skoordynowana akcja zbierania odpowiedzi na Fragebogenberichte trwała przede wszystkim w latach 1952-1959. Objęła zwłaszcza dawne prowincje wchodzace w skład Rzeszy Niemieckiej, obecnej Polski. Zgromadzony, stosunkowo obszerny materiał pozwolił w 82,5\% ustalić losy Niemców na terenach - jak to wówczas określano - na wschód od Odry i Nysy („ostwärts der Oder/Neiße”). Na zgromadzony zbiór składa się 1461 Fragebogenberichte $\mathrm{z}$ gmin $\mathrm{z}$ tzw. Kraju Warty i Polski oraz 16671 relacji z obszarów Rzeszy Niemieckiej (prowincji Pomorze, Górny i Dolny Ślassk, Prusy Wschodnie), włącznie z polskimi powiatami pomorskimi (Pomorze Gdańskie) ${ }^{3}$. W zespole tym znajdziemy również inne informacje dotyczace losów Niemców na terenie Czech, Słowacji, Węgier, Jugosławii, Rumunii. Niemieckojęzyczna nazwa tego zespołu z liczba prawie 20000 relacji jest następująca: Fragebogenberichte (Gemeindeschicksalsberichte) zur Dokumentation der Vertreibung der Deutschen aus Ostmitteleuropa und aus den deutschen Siedlungsgebieten in Südosteuropa nr 1, 20, 17. Do zespołu nr 1 dołączony jest odrębny zespół, który funkcjonuje pod nazwa Dokumentacja Wschodnia 1. Dodatek. Kwestionariusze o zbrodniach i prześladowaniach dokonanych na Niemcach podczas wypędzenia (Ost-Dokumentation 1 Anhang. Erhebungsbögen über Verbrechen und Unmenschlichkeiten, die an Deutschen im Zuge der Vertreibung begangen worden sind5). Ten zbiór składa się z 5500 kwestionariuszy, które zostały opracowane na podstawie aktu prawnego niemieckiego ministra spraw wewnętrznych o zebraniu i opracowaniu materiału o zbrodniach na Niemcach. Tego rodzaju materiału bezpośrednio dotyczy prześladowania ludności niemieckiej będaccej w obozach i innych miejscach odosobnienia. Ma pokazywać cierpienia Niemców na tych terenach. Takie było zamierzenie pomysłodawcy.

Drugi zespół Ost-Dokumentation w Bayreuth, pod nazwą Erlebnisberichte zur Dokumentation der Vertreibung der Deutschen aus Ost-Mitteleuropa, Sudetenland und Südosteuropa (Dokumenta-

${ }^{3}$ Bundesarchiv Bayreuth, Ost-Dokumentation 1. Fragebogenberichte zur Dokumentation der Vertreibung aus Ost-Mitteleuropa (Gemeindeschicksalsberichte). 
cja Wschodnia. Relacje składające się na dokumentację wypędzenia Niemców z Europy Środkowo-Wschodniej, Kraju Sudeckiego i Europy Południowej), tworzy 9975 osobistych przeżyć Niemców. Część relacji osób zamieszczonych w zespole Ost-Dokumentation ukazała się w ramach kilkutomowego wydawnictwa pt. Die Vertreibung der deutschen Bevölkerung aus den Gebieten östlich der Oder-Neiße. Tom pierwszy, złożony $z$ trzech części, wydany przez Ministerstwo ds. Wypędzonych, Uciekinierów i Poszkodowanych przez Wojnę został wydrukowany po raz pierwszy w latach 19541960 i doczekał się kolejnych wydań ${ }^{4}$. Relacje obejmuja okres od początku walk do i bezpośrednio po kapitulacji; wypędzenie (Vertreibung/Austreibung), wysiedlenie, deportowanie. Prace nad zbieraniem tych relacji rozpoczęto w 1950 r. i zakończono w 1953 r. Zbierano je na zlecenie Ministerstwa ds. Wypędzonych, Uciekinierów i Poszkodowanych przez Wojnę. Na zespół liczący ogółem 9975 relacji składa się: 6207 relacji od osób z terenów dawnej Rzeszy Niemieckiej i Polski (Reichsgebiet und polnische Raum); 1831 relacji z Sudetów i Protektoratu Czech i Moraw (Sudetenland und Protektorat Böhmen und Mähren); 1937 z Europy Południowo-Wschodniej (Südostraum).

W ramach Ost-Dokumentation wyodrębniono jeszcze inne podzespoły, które de facto otrzymały własną numerację. Jest to zespół Ost-Dokumentation 4. Unterlagen zur Flucht über die Ostsee (Materiały dotyczace ewakuacji i ucieczki Niemców przez Morze Bałtyckie), który dotyczy losów Niemców, ich przeżyć podczas ucieczki, ewakuacji, oraz Ost-Dokumentation 7. Berichte von Deutschen in Polen über die Ereignisse im September 1939 (Relacje Niemców zamieszkałych w Polsce o wydarzeniach we wrześniu 1939 r.), będący zbiorem relacji o przeżyciach Niemców podczas agresji Trzeciej Rzeszy na Polskę we wrześniu 1939 r.

Zespół Ost-Dokumentation stał się podstawą do publikacji takich jak tzw. niebieska księga, dokumentująca zbrodnie wypędzenia w świetle relacji. Została opublikowana w 1974 r.

Niewatpliwie „Bayreuthiana” w formie relacji pisemnych osób maja charakter bardzo subiektywny. Nad powstaniem tego rodzaju źródeł czuwały instytucje rządowe, partie chadeckie (Unia Chrześcijańsko-Demokratyczna [CDU] i Unia Chrześcijańsko-Spo-

${ }^{4}$ Die Vertreibung der deutschen Bevölkerung aus den Gebieten östlich der OderNeiße, hrsg. vom ehemaligen Bundesministerium für Vertriebene, Bd. I/ 1 - I/3, Flüchtlinge und Kriegsgeschädigte Augsburg 1993 (Sonderausgabe). 
łeczna w Bawarii [CSU]), którym zależało na udokumentowaniu dokonanych krzywd i prześladowań Niemców przez stronę polską i sowiecka. $Z$ jednej strony zebranie tego rodzaju materiału miało obrazować skalę dokonanych zbrodni po wojnie na Niemcach, a $z$ drugiej chodziło o pozyskanie sympatii środowisk wypędzonych dla partii CDU i CSU. W relacjach przechowywanych w Bayreuth pojawia się obraz powojennych tragedii Niemców w postaci utraty domostw, mienia, tułaczki, pobytu w obozie, więzieniu, śmierci najbliższych itp. Nader często sprawozdawca widzi wojnę przez pryzmat wyłącznie własnych doznanych krzywd i zapomina o związku przyczynowo-skutkowym, że to, co się stało, ma swoje podłoże w minionym konflikcie zbrojnym. Wymiar całego przedsięwzięcia, tj. zebrania relacji, miał niewątpliwie charakter polityczny. Dysponujemy dzięki temu materiałem, który może być przedmiotem badań i krytycznej oceny.

Dla badacza drugiej wojny światowej na szczególną uwage zasługuje zespół Ost-Dokumentation numer 8. Jego pełna nazwa brzmi: Berichte von Persönlichkeiten des öffentlichen Lebens aus den Gebieten östlich von Oder und Neisse zum Zeitgeschehen 1919-1945. Intelligenzberichte. W tłumaczeniu na język polski są to „Sprawozdania osób sprawujących funkcje publiczne na obszarach na wschód od Odry i Nysy Łużyckiej w latach 1919-1945. Sprawozdania inteligencji”. Zespół ten złożony jest z 383 jednostek archiwalnych, co w sumie składa się na setki stron sprawozdań. Te zostały sporządzone w latach pięćdziesiątych przez osoby, które zajmowały podczas drugiej wojny światowej różne funkcje. Nad powstaniem tego zespołu czuwała Specjalna Komisja Naukowa, która została powołana w celu realizacji tego projektu badawczego. Określiła interesujące ja problemy badawcze, jak organizacja niemieckiej administracji i działania władz okupacyjnych podczas drugiej wojny światowej w celu realizacji określonej polityki narodowościowej NSDAP i innych jej przybudówek; życie codzienne i nastroje Niemców na Wschodzie podczas wojny; posunięcia gospodarcze, udział niemieckiego kapitału i niemieckich zasobów ludzkich w celu połączenia zdobytych terytoriów z tzw. Rzeszą właściwa; życie kulturalne na zdobytych przez Trzecia Rzesze terenach; relacje polsko-niemieckie i polski ruch oporu; plany ewakuacji i ucieczka ludności niemieckiej z zajętych obszarów. Sprawozdawcami stali się różnego szczebla inspektorzy, geodeci, księża, aptekarze, leśniczy, nauczyciele, starostowie, kierownicy 
urzędów finansowych, skarbowych, gazowni, nadprezydenci. Raport Specjalnej Komisji Naukowej został sporządzony po drugiej wojnie światowej, w 1955 r. Jest to jeden $z$ tego rodzaju zbiorów znajdujacych się w zbiorach Ost-Dokumentation.

Niewatpliwie Ost-Dokumentation o numerze 8 (Nr. 8) to specyficzny, subiektywny materiał osób, urzędników, przedstawicieli różnych zawodów, którzy podczas drugiej wojny światowej byli jednym $z$ ogniw w systemie politycznym totalitarnego państwa Trzeciej Rzeszy. Po wojnie piszac swoje raporty, nie przedstawiali siebie w negatywnym świetle, unikali opisu wielu sytuacji, za które powinni wziąć czy też ponosili współodpowiedzialność jako okupanci. Niezależnie od tego rodzaju uwarunkowań opisali pewien stan rzeczy, który po krytycznej analizie źródła uzupełnia nam obraz drugiej wojny światowej. Jedno $z$ takich sprawozdan, liczacy trzy strony, dotyczy getta łódzkiego. Autor artykułu wszedł w posiadanie tego źródła w wyniku kwerendy naukowej przeprowadzonej w latach 2000-2002 w ramach uzyskanego stypendium naukowego Fundacji Alexandra von Humboldta (Alexander von Humboldt-Stiftung). Kwerenda źródłowa autora objęła cały zespół Ost-Dokumentation, w szczególności ten o numerze 8 (Nr. 8). W wyniku kilkutygodniowej kwerendy w archiwum w Bayreuth udało się odkryć autorowi źródło, które wcześniej nie było analizowane, poddane krytyce źródłowej.

Autorem sprawozdania dotyczącego getta łódzkiego jest Friedrich Prager, który był urzędnikiem wyższego szczebla podczas wojny. Po wojnie osiadł w Republice Federalnej Niemiec, w mieście Garmisch-Partenkirchen i w 1955 r. spisał swój raport. Nie udało się na tym etapie ustalić dokładnego życiorysu F. Pragera, ze szczególnym uwzględnieniem jego wątków biograficznych $z$ czasów drugiej wojny światowej. Autor ma jednak nadzieję, że dalsze badania archiwalne, zwłaszcza w archiwach niemieckich, pozwola na dokładne ustalenie biografii F. Pragera w kontekście jego kariery urzędniczej w systemie totalitarnego państwa Trzeciej Rzeszy. Ważne jest, aby przeprowadzenie badań archiwalnych, egzegezy materiałów źródłowych pozwoliło udzielić odpowiedzi na pytania, w jakich okolicznościach i dlaczego F. Prager znalazł się na terenie getta łódzkiego, czy sporządzone przez niego sprawozdanie jest jedynym materiałem bądź też istnieją podobne opisy $z$ tego samego getta lub innych miejsc zwiazanych $z$ tragicznymi losami ludności żydowskiej. 
Getto łódzkie było jednym $z$ wielu gett utworzonych na ziemiach polskich podczas drugiej wojny światowej. Getta były składowa polityki ludobójstwa Trzeciej Rzeszy wobec społeczności żydowskiej. Słusznie ujał to Artur Eisenbach: „Instytucja gett była typowym przykładem zorganizowanej zbrodni ludobójstwa. Od zarania getto było pomyślane i traktowane jako instrument fizycznego wyniszczenia osadzonej w nim ludności [...]"5. Tworzenie gett tłumaczono zachowaniem względów bezpieczeństwa. Koncentracja Żydów w określonej części miasta, ich izolacja była uzasadniana możliwością ich udziału w akcjach partyzanckich czy też zapobieganiu przed uprawianiem wrogiej propagandy wobec Trzeciej Rzeszy. W rzeczywistości był to jeden $z$ elementów ludobójstwa Żydów. Pierwsze getto powstało w październiku 1939 r. w Piotrkowie, w grudniu w Puławach i Radomsku. Na wiosnę 1940 r. zaczęto tworzyć getta w powiecie jędrzejowskim (Jędrzejów, Włoszczowa, Wodzisław), Rakowie, Przedborzu. W maju 1940 r. powstały getta w miastach powiatu łowickiego (Łowicz, Głowno, Bolimów, Kiernozja). W lutym 1940 r. powstało getto (zamknięta dzielnica) w Pabianicach, w kwietniu w Brzezinach, w maju w Szadku i Krośniewicach. W kolejnych miesiacach utworzono getto w Kutnie (16 czerwca) i Żychlinie (9 lipca). W drugiej połowie $1940 \mathrm{r}$. i na początku 1941 r. założono getta we Włocławku, Poddębicach, Uniejowie, Kole i Łęczycy ${ }^{6}$. Getto w Łodzi powstało z początkiem 1940 r. Prezydent policji łódzkiej w okupacyjnym okręgu Rzeszy (Reichsgau) Warthegau Schäfer wydał 8 lutego 1940 r. zarządzenie wykonawcze, w którym wyznaczył teren getta w Łodzi i sposoby przeniesienia do niego Żydów. Getto łódzkie był jednym z największych gett utworzonych przez Niemców na ziemiach polskich i najdłużej funkcjonującym. Przeszło przez nie około 200 tys. osób. Obok roli wyniszczenia Żydów jak w pozostałych gettach, getto łódzkie było podporządkowane funkcji przemysłowej na rzecz produkcji Trzeciej Rzeszy. W getcie zlokalizowano wiele zakładów produkcyjnych produkujacych na potrzeby niemieckiego wojska. W 1944 r. zakłady getta były w stanie produkować dziennie całkowite umundurowanie dla 5 tys. żołnierzy, $z$ wyjątkiem obuwia. Praca w zakładach produkcyjnych, istnienie getta była cena za przeżycie, jaka płacili Żydzi łódzcy. Nie chroniło to ich przed różnego rodzaju akcjami eksterminacyjnymi, wywózkami. $Z$ począt-

\footnotetext{
${ }^{5}$ A. Ei s e n ba ch, Hitlerowska polityka zagłady Żydów, Warszawa 1961, s. 227.

${ }^{6}$ Ibidem, s. 218, 219, 226.
} 
kiem czerwca 1944 r. Heinrich Himmler wydał rozkaz likwidacji getta, w którym żyło i pracowało około 70 tys. osób. Jedynie około od 5 do 7 tys. Żydów przeżyło łódzkie getto ${ }^{7}$.

Poniższe sprawozdanie sporządzone przez wspomnianego niemieckiego urzędnika (Friedrich Prager) w okresie powojennym jest źródłem wyjątkowym. Nie spotykamy tego rodzaju źródeł. Po dziesięciu latach od zakończenia wojny urzędnik niemiecki sporządza sprawozdanie $z$ miejsca, getta, które $z$ premedytacja zostało zlikwidowane przez niemieckie władze okupacyjne, przestało istnieć. W relacji F. Prager charakteryzuje getto jako normalnie funkcjonujące miejsce, autarkiczne getto, w którym żyją i pracują Żydzi. Nie wnika w rzeczywiste, katastrofalne warunki życia większości mieszkańców getta. Wręcz przeciwnie, skupia się na majętnych Żydach, którzy dzięki swoim kosztownościom wiedli dostatnie życie w przeciwieństwie do pozostałych Żydów tłoczących się w małych mieszkaniach. Ze sprawozdania wynika, że getto łódzkie było dużym zakładem produkcyjnym stworzonym na potrzeby niemieckiego wojska. Prager powtarza, że w getcie był największy w Europie zakład krawiecki szyjący mundury dla wojska.

Dla czytelnika tego rodzaju źródło jest sporządzonym zapisem przez Niemca, który usiłuje przedstawić getto łódzkie jako $z$ pozoru normalnie funkcjonujacy obszar miasta dla Żydów w realiach wojny. Prager relacjonuje, że w „dzielnicy mieszkalnej znajdowały się dwa własne szpitale i kilka aptek”. Zastanawia się, „czy miały one wszystkie konieczne środki medyczne i farmaceutyczne”. Wspomina o panujących chorobach zakaźnych i działaniach zapobiegających rozprzestrzenieniu się epidemii. Charakteryzuje życie codzienne w getcie przez pryzmat kobiet robiacych w pospiechu zakupy, „dźwięk dzwonków sklepowych” oraz spacerującej młodzieży, osób starszych po ulicach, próbujących „złapać promienie słońca”. Prager skrzętnie zapisał w sprawozdaniu, że „nigdzie nie było widać niezadowolonej miny". Dodał także, że podczas wizyty jego i innych hitlerowskich notabli w mieście nie przejawiano wobec nich „negatywnego nastawienia”. W sprawozdaniu jego autor usiłuje podkreślić wewnętrzny podział na Żydów, tych majętnych i normalnie pracujacych. Przy czym F. Prager podkreśla zgromadzenie przez bogatych Żydów już przed wojna kosztowności, złota, biżuterii, aby móc normalnie funkcjonować i żyć. Sporządzone spra-

7 Ibidem, s. 558, 560, 570; A. Sitarek, Otoczone drutem państwo. Struktura i funkcjonowanie administracji żydowskiej getta łódzkiego, Łódź 2016, s. 309. 
wozdanie, zawierające nieprawdziwy obraz rzeczywistości w getcie łódzkim, nasuwa badaczowi zapytanie o cel tego zabiegu dokumentacyjnego. Czy autor sprawozdania podjął próbę relatywizacji zdarzeń, tj. drugiej wojny światowej, Holokaustu? Jeżeli miałaby być to próba wybielenia zbrodniczej polityki Trzeciej Rzeszy wobec narodów okupowanych, ludności żydowskiej podczas drugiej wojny światowej przez urzędnika niemieckiego, można stwierdzić, że ze znajomością całego kontekstu zdarzeń zabieg ten w swoim wymiarze jest nieudolny. Biorac jednak pod uwage czas powstania sprawozdania, tj. rok 1955, należy pamiętać, że jest to przedział czasowy, w którym problem rozliczenia zbrodni hitlerowskich, niemieckich nie jest przedmiotem zainteresowania powstałych państw niemieckich (RFN, NRD) czy też zachodniej opinii publicznej w dobie tzw. zimnej wojny. Wskutek braku zainteresowania dokonanymi przez Trzecią Rzeszę zbrodniami niemieckimi podczas wojny wielu zbrodniarzy nie stanęło przed wymiarem sprawiedliwości, a co więcej - wielu $z$ nich wiodło normalne życie ${ }^{8}$. Sporządzone przez F. Pragera sprawozdanie jest źródłem dostarczającym nam zapisu dokonującej się zbrodni Holokaustu na ludności żydowskiej (pozbawienie Żydów wolności, praw, oznakowanie, zamknięcie w getcie). Sprawozdanie obejmuje okres stosunkowo długi, bo od 1940 r. do listopada 1941 r., a jest lakoniczne. Biorac pod uwage cezurę końcowa tego sprawozdania, należy uwypuklić, że to zaledwie niespełna trzy miesiace przed tragiczna datą, tj. 20 stycznia 1942 r., gdy funkcjonariusze Trzeciej Rzeszy na spotkaniu w Wannsee omówili kwestię ostatecznego rozwiązania kwestii żydowskiej, dokonania ludobójstwa Żydów. W tym szerszym kontekście warto źródło to prześledzić, gdyż ukazuje nam miejsce - getto łódzkie, mieszkających w nim Żydów, którzy stali się ofiarą zaplanowanego, niespotykanego w historii Holokaustu Żydów.

8 Szerzej o ściganiu i problemie karania zbrodni hitlerowskich, niemieckich por. W. Stankowski, Szymon Wiesenthal. Biografia, Warszawa 2009. 


\section{TEKST ŹRÓDLOWY}

Raport specjalny dotyczący warunków życia w getcie południowym w Łodzi w okresie styczeń 1940 - listopad 1941 r.

Garmisch-Partenkirchen, 10 listopada 1955

Friedrich Prager, dyrektor rządowy w stanie spoczynku

[s. 1] Ze względu na to, że z pewnością niewiele osób miało okazję odwiedzić getto, chcę o nim opowiedzieć.

Jak już wspomniano, dzielnica żydowska leżała tam, gdzie od zawsze mieszkali głównie Żydzi. Tylko teraz wszystko było otoczone drutem kolczastym, poza tym w celu ochrony przed pożarem $z$ wyburzonych domów stworzono strefę bezpieczeństwa. Przez środek getta przechodziła linia tramwajowa, jednakże odgrodzona po każdej stronie ulicy drutem kolczastym tak, aby podczas przejazdu można było obserwować życie i to, co się dzieje w getcie (zakaz wysiadania!). Połączenie między oddzielonymi częściami było możliwe dzięki bramkom, przez które policja porządkowa przeprowadzała grupy osób. Nosiła ona szare czapki narciarskie i drewniane pałki. Później między obiema częściami miasta wybudowano kładki i ruch dokonywał się już bez przeszkód. Były one zawsze pełne Żydów, którzy wykorzystywali je jako wieże widokowe. Kiedy wieczorem wracało się przez getto $z$ podróży służbowej, odnosiło się wrażenie, że wszyscy jego mieszkańcy, ok. 30 000, w tym samym czasie wybrali się na spacer. Kobiety w pośpiechu robiły zakupy, słychać było dźwięk dzwonków sklepowych. Młodzież przechadzała się po ulicach, starzy siedzieli na ławkach, próbując złapać ostatnie promienie słońca.

W dzielnicy mieszkalnej znajdowały się dwa własne szpitale i kilka aptek, jednakże nie wiem, czy miały one wszystkie konieczne środki medyczne i farmaceutyczne. Getto było tzw. gettem pracy, tzn. mieszkańcy (osadzeni) pracowali, aby utrzymać siebie i swoich towarzyszy ${ }^{9}$. Mówiono, że znajdował się tutaj największy w Euro-

${ }^{9}$ Getto łódzkie wyróżniało się spośród wszystkich gett utworzonych podczas drugiej wojny światowej. Produktywizacja więźniów getta, rozbudowany system fabryk służył celom wojennym Trzeciej Rzeszy. Miał także w świetle żydowskiej administracji zapewnić samowystarczalność getta i ochronić przed Zagłada. Tak o getcie we wspomnieniach napisała wiedeńska Żydówka Alice de Buton: „pracuje 
pie zakład krawiecki szyjący mundury. Były tutaj również wielkie zakłady stolarskie, przeważnie dla mieszkańców ${ }^{10}$. W getcie panowały straszne choroby zakaźne. Aby nie rozprzestrzeniały się one na miasto i kraj, podczas dostawy surowców, np. materiałów i desek, oraz podczas opuszczania getta $z$ gotowymi towarami należało za każdym razem przejść przez strefę dezynfekująca. O ile wiem, nigdy nie doszło do przeniesienia choroby na zewnattrz. [s. 2]

Żydzi mieli swoją własną administrację, własną policję, własne szkoły i własne pieniądze. Najstarszy z Żydów burmistrz był wyrazista osobowością (sam go widziałem) $z$ charakterystyczna twarzą i falowanymi, całkiem posiwiałymi włosami ${ }^{11}$. Jego sekretarką była młoda adwokatka $z$ Łodzi ${ }^{12}$. Jego ochroniarzem i szefem jego policji był olbrzymi facet, były zapaśnik czy bokser, który nosił w butonierce Order Krzyża Żelaznego z I wojny światowej. Obu poznałem podczas wizyty, która składał w getcie minister Rzeszy Rust ${ }^{13}$, i do

dla potęgi niemieckiej. Getto to dorównuje przemysłowemu miastu [...]". A. Sitarek, op. cit., s. 312.

${ }^{10}$ We wrześniu 1940 r. w getcie łódzkim było 17 różnych zakładów produkcyjnych. Natomiast już w lipcu 1941 r. w getcie utworzono 45 wielkich przedsiębiorstw przemysłowych. Było w nich zatrudnionych 45 tys. Żydów. W 1942 r. w lipcu było w getcie 74 zakłady zatrudniające 69 tys. robotników żydowskich. W sierpniu 1942 r. było 91 zakładów, w których morderczą pracę wykonywało 78 tys. Żydów. Żydzi byli zatrudnieni w sektorze metalowym (5317 robotników), drzewnym (4463 robotników), skórzanym (11 570 robotników), włókienniczym (28 754 robotników), w innych gałęziach (10 096). A. Eis en bach, op. cit., s. 448,562 .

${ }^{11}$ Chodzi o Chaima Mordechaja Rumkowskiego, który w getcie miał najwyższą funkcję administracyjną wśród społeczności żydowskiej. Był Przełożonym Starszeństwa Żydów (der Älteste der Juden). Jego zachowanie i sposób działań w getcie jest do dziś przedmiotem kontrowersji i sporów. Rumkowski określał siebie w getcie jako dyktator. Został zamordowany wraz ze swoja rodzina w KL Auschwitz-Birkenau. A. Sitarek, op. cit., s. 47; M.M. Midlarsky, Ludobójstwo wXX wieku, Warszawa 2010, s. 253.

12 Chodzi o Reginę Wajnberger, druga żonę Chaima Rumkowskiego, która poślubił w 1941 r. Regina Wajnberger urodziła się 22 V 1907 r. w Łodzi. Ukończyła studia prawnicze na Uniwersytecie Warszawskim, po których rozpoczęła aplikację sędziowską w sądzie łódzkim. Podczas wojny pełniła funkcję radcy prawnego w sekretariacie Przełożonego Starszeństwa Żydów. W sądzie żydowskim była obrońca i adwokatem w sprawach rozwodowych, stąd określano ja jako adwokat, jednak nie miała aplikacji adwokackiej. Autor sprawozdania błędnie podaje, że była to sekretarka C. Rumkowskiego. Z racji bliskich kontaktów, późniejszego zwiąku małżeńskiego tak można było domniemywać. Wówczas prawą ręką C. Rumkowskiego była Dora Fuchs, kierowniczka Centralnego Sekretariatu i tłumaczka. A. Sitarek, op. cit., s. 292, 294, 301.

${ }_{13}$ Bernhard Rust był ministrem nauki, wychowania i oświaty ludowej w latach 1933-1945. Należał do starej gwardii Narodowosocjalistycznej Niemieckiej Partii 
której zostałem powołany. Samochody przejechały przez bramy i strefę kwarantanny, a następnie przez ulice pełne ludzi i pojazdów. Wzbudzały zainteresowanie, gromadził się ciekawski tłum, ale bez negatywnego nastawienia. Do akcji natychmiast wkroczyła żydowska policja i usprawniła ruch na ulicy, jednak w niezbyt delikatny sposób. Niewiele mówiąc, bili ciekawskich drewnianymi pałkami, zmuszając ich do rozejścia się. Ministrowi pokazano fabrykę tekstyliów, w której produkowano damska odzież wierzchnia, a dokładniej chodziło o pikowane szlafroki wg paryskich i wiedeńskich wzorów $z$ dobrych materiałów w najmodniejszych kolorach. Następnie zwiedzano jeszcze duży zakład krawiecki szyjący mundury. Wrażenie całości $z$ taką masą ludzi było trochę przygnębiające, chociaż nigdzie nie było widać niezadowolonej miny ${ }^{14}$.

To, o czym teraz napiszę, pochodzi z opowiadań w kasynie od człowieka, którego można było uważać za odpowiedzialnego za getto. Getto było gettem pracy, więc jako takie musiało się samo utrzymać, tzn. zdolni do pracy musieli pracować na niezdolnych do pracy ewentualnie zdobywać środki na szpitale, apteki i pozostałe instytucje użyteczności publicznej. Administracja getta była w rękach Miasta Łódź, nadzór zewnętrzny należał do policji gminnej, a wewnętrzny do samych Żydów. $Z$ dochodów uzyskiwanych $z$ pracy pokrywano koszty wyżywienia mieszkańców (osadzonych) w getcie. Te jednak nie wystarczały na utrzymanie getta. Wiadomo było, że chociaż było to zabronione, Żydzi wzięli ze sobą do getta metale i kamienie szlachetne o wielkiej wartości. [s. 3]

Administracja Miasta Łódź próbowała powetować sobie nimi swoje straty. Jak wszędzie na świecie wielką rolę odgrywała tam denuncjacja. Jacyś zirytowani ludzie wydawali tych, co ich zirytowali, niemieckiej policji, a ta potem wkraczała do akcji. Opowiadano, że Żydzi już na rok przed wybuchem wojny przygotowali się na wkroczenie Niemców, budują $z$ pomoca murarzy i stolarzy kryjówki w ścianach, na strychach, a nawet całych piętrach, które następnie mogły zostać wykorzystane i zamurowane podczas wybuchu wojny lub wkroczenia wojsk niemieckich. Przygotowy-

Robotników (NSDAP). R.S. Wistrich, Kto był kim w III Rzeszy. Leksykon, Kraków 1997, s. 185.

${ }^{14}$ Zawsze podczas wizyt wysokich funkcjonariuszy partyjnych Trzeciej Rzeszy: czy to w gettach, czy w obozach koncentracyjnych, nakazywano więźniom, robotnikom przymusowym pod groźba śmierci właściwe zachowanie i okazywanie zadowolenia $z$ wykonywanej pracy. Autor sprawozdania nie mógł o tym nie wiedzieć czy też nie zdawać sobie $z$ tego sprawy. 
wano takie możliwości nawet na otwartym polu, co potwierdziło takowe odkrycie. Znaleziono tam cenne obrazy i dywany, zapasy jedzenia i kosztowności, wszystko wielokrotnie szczelnie zapakowane i przygotowane do długiego składowania. W wielu takich przypadkach nie postępowano jednak sprytnie. I tak jeden $z$ agentów w pewnym domu zauważył, że schody kończyły się bezpośrednio przy murze. Przebito ścianę i odkryto cenny magazyn futer. W innym przypadku odkryto korespondencję między gettem warszawskim a 1 . gettem. Na kartce pocztowej $z$ dziwnym napisem „polecony” znaleziono ukryta uwage, że nadawca pilnie potrzebuje pieniędzy. Policja przemyciła do Warszawy swojego łącznika, kazała mu wyszukać kontakty, potem aresztowała pośrednika nadawcy kartki, należącego do jednej $z$ najbogatszych żydowskich rodzin w Łodzi, przesłuchała go, a następnie znalazła w getcie biżuterię, której wartość eksperci wycenili na grubo ponad 1 milion marek. Była ona ukryta pod stara owczarnia, zakopana, wielokrotnie szczelnie opakowana i starannie ułożona w przygotowanych skrzyniach. Biżuterię i kamienie szlachetne sprzedawano w getcie nawet na ulicy, ponieważ wiele majętnych rodzin także w getcie posiadało porządne mieszkanie, podczas gdy biedniejsi musieli się tłoczyć w pomieszczeniach po 40-50 osób, które normalnie były przeznaczone dla połowy takiej liczby. Aby zdobyć dodatkowe artykuły spożywcze, sprzedawali swoją biżuterię. $Z$ tego względu Miasto Łódź utrzymywało w mieście policję kryminalną, która kontrolowała handel uliczny. Dochodziło przy tym do niewiarygodnych scen, kiedy wkraczano do akcji i w niezliczonych kieszeniach garniturów i schowkach ulicznych sprzedawców szukano złota i kamieni szlachetnych. Miało to miejsce jednak dopiero wtedy, kiedy wzbudzali oni podejrzenia lub zostali zadenuncjowani ${ }^{15}$.

\section{Data: 22.11.1955}

Friedrich Prager, Dyrektor rządowy w stanie spoczynku Garmisch-Partenkirchen

15 Jednym $z$ celów polityki Trzeciej Rzeszy wobec Żydów było pozbawienie ich wszelkiego majątku. Deportacja do gett oznaczała konfiskatę mieszkania, domów, kosztowności, sprzętów itp. rzeczy. Nawet jeżeli Żydom udało się zachować, przemycić do getta pewne kosztowności, jak biżuterię czy złoto, Niemcy starali się o tym dowiedzieć i zrabować resztki mienia. W tym celu w getcie łódzkim w połowie maja 1940 r. powstał specjalny urząd Sonderkommando Kripo, którego głównym zadaniem było zbieranie wszelkich informacji o przechowywaniu przez Żydów 


\section{Bibliografia}

\section{ŹRódeA ARChIWALNe}

Archiwum Federalne w Bayreuth (Bundesarchiv Bayreuth)

Ost-Dokumentation Nr. 1;

Ost-Dokumentation Nr. 8.

\section{ŹRódea DRUKOWANE}

Die Vertreibung der deutschen Bevölkerung aus den Gebieten östlich der Oder-Neiße, hrsg. vom ehemaligen Bundesministerium für Vertriebene, Bd. I/ 1 - I/3, Flüchtlinge und Kriegsgeschädigte Augsburg 1993 (Sonderausgabe).

\section{OpRacowania}

Eisenbach A., Hitlerowska polityka zagłady Żydów, Warszawa 1961.

Midlarsky M.M., Ludobójstwo w XX wieku, Warszawa 2010.

Sitarek A., Otoczone drutem państwo. Struktura i funkcjonowanie administracji żydowskiej getta łódzkiego, Łódź 2016.

Stankowski W., Szymon Wiesenthal. Biografia, Warszawa 2009.

Wistrich R.S., Kto był kim w III Rzeszy. Leksykon, Kraków 1997.

Witold STANKowski

JaGiellonian University in Kraków/Pilecki Institute in WarsaW

\section{"Bayreuthiana" as a source to research of the Second World War in the light of reports of a German clerk from the Litzmannstadt Ghetto as a case study}

P resented article describes material, source resources as Eastern Dokumentation 1 (Ost-Dokumentation). In the light of relations deposited in the team, author presents the living conditions of Jewish community in the Litzmannstadt Ghetto during the Second World War which was reported by the one of German clerk. This report was written after the end of the war and was placed in archival collection storaged in German city named Bayreuth. From the name of this city, author has implemented a term „Bayreuthian” for archival collections which were placed in Bundesarchiv - Federal Archive in Bayreuth in Bavaria in Federal Republic of Germany. „Bayreuthiana” is the term which had been not functioning in previous times in a Polish and German historiography. Archival collections

wartościowych przedmiotów. Sonderkommando Kripo miało uprawnienia do przeprowadzania rewizji i rekwirowania wartościowych rzeczy, jak złota, brylantów, futer. A. Eisen bach, op. cit., s. 195; M.M. Midlarsky, op. cit., s. 254. 
which are there located, they are rich source of information about social history, interpersonal relations, German-Polish relations during interwar period, also Second World War, and after 1945.

Undoubtedly the "Bayreuthiana” in the form of written reports, they are subjective. However, they are a still specific source of information. One of this kind of report has three pages and is about ghetto in tódź. Friedrich Prager is the author and what is more, he was a clerk of higher administrative level during war. After war he was living in Garmisch-Partenkirchen and in 1955 his report was made. In his report, he shows Litzmannstadt Ghetto, daily conditions there, daily life, and behaviors of Jewish community. He has tried to present normal living conditions of Jews and also to show functioning of different institutions such as grocery stores, pharmacies or hospitals.

Keywords: Second World War, genocide policy of Third Reich, Jewish community, Litzmannstadt Ghetto, daily life in Ghetto, archival sources. 